\title{
Supramoléculas Fotoiónicas: Mobilizando as Brigadas Carga e Luz*
}

\author{
A. PRASANNA DE SILVA, THORFINNUR GUNNLAUGSSON, COLIN P. MCCOY
}

Muita da informação acerca do que nos rodeia chega até nós, sob a forma de fotões, através dos nossos olhos. Os nossos olhos contêm sistemas moleculares capazes de receber estes sinais ambientais e de, por fim, os converter em correntes de iões sódio e potássio nos nervos ópticos. Estes estão ligados ao nosso cérebro, onde as mensagens são de novo processadas, armazenadas e usadas. Os sistemas de rodopsina existentes nas células retinais dos nossos olhos [1] são talvez os exemplos mais importantes de supramoléculas ou supermoléculas fotoiónicas. Contudo, químicos de todo o Mundo têm vindo a idealizar e a construir sistemas mais simples para uma variedade de utilizações, que são o tema deste artigo. Muitas dessas utilizaçōes derivam do facto de vários iões, metálicos e não-metálicos, serem responsáveis pela nossa saúde, ou pela sua destruição.

Em geral, uma supramolécula fotoiónica possui pelo menos dois componentes moleculares com zonas que interactuam com fotões e iões, respectivamente [2-4]. Uma supramolécula deste tipo torna-se particularmente interessante quando estes dois componentes podem também interactuar, de algum modo, entre si. Torna-se fácil encontrar moléculas com zonas que interactuem com fotões ou iões, quando recordamos que os iões contêm cargas electrónicas e que fotões e ondas electromagnéticas são as duas faces da luz. Os electrões nas moléculas constituem um meio na- tural para enredar qualquer uma destas espécies eléctricas. Moléculas que interagem com fotōes estão obviamente disponiveis entre os cromóforos dos corantes - os produtos mais visiveis da química. Os corantes absorvem luz de cores específicas, incluindo comprimentos de onda que para nós são invisíveis. Alguns deles são também fluoróforos ou fosforóforos(?), quando emitem parte da energia luminosa inicialmente absorvida. Os componentes moleculares que interactuam com iões podem ser encontrados entre os ligandos e receptores da química de coordenação e da sua prima mais nova, a química supramolecular. Partindo destas fontes de componentes moleculares, os "designers" de supramoléculas fotoiónicas podem trabalhar com luz numa miriade de cores e com os iões numa variedade de cargas, formas e tamanhos.

\section{Iões que disparam cor}

\section{Ion-Triggered Color}

Desde os tempos dos primeiros alquimistas, as mudanças de cor têm constituido um dos modos mais directos para detectar interacçōes moleculares. Este năo é feito de pouca monta, se tivermos em conta que as moléculas em causa são biliões de vezes mais pequenas do que aqueles que as observam. Alguns dos exemplos mais bem conhecidos de supramoléculas fotoiónicas baseiam-se na absorção de luz seguida de transmissão ou reflexão da mesma como sinal de saída ("output") [5]. Por exemplo, o indicador, ou sensor de $\mathrm{pH}$, fenolftaleína (1), é provavelmente a primeira molécula a causar uma impressão visivel em diversas gerações de estudantes nas escolas do mundo inteiro, sendo o personagem principal da transformação colorida da "água em vinho". Quando em contacto com uma soluçã̃o aquosa de hidróxido de sódio, a forma incolor $\mathbf{1}$ transforma-se na forma vermelha 2. Uma observação rápida da estrutura $\mathbf{2}$ mostra a existência de um sistema de electrões $\pi$ deslocalizados ao longo da molécula, responsável pela forte cor vermelha. 0 sítio de interacção com o fotão abrange assim toda a molécula. Um olhar mais cuidadoso revela as unidades fenolato, cujos átomos de oxigénio funcionam como locais receptores de protões, e que permanecem desprotonadas em solução alcalina. Após adição de protões, 2 converte-se em 1 , que contém vários sistemas mais pequenos de electröes $\pi$. Neste caso, a supramolécula 2 tem o sítio receptor de protões sobreposto ao sítio que interage com os fotōes. Este "design" simples tem sido uma característica utilizada em muitos sensores ópticos para iões, inspirados no sucesso do exemplo clássico $\mathbf{1} \geq \mathbf{2}$. A molécula $\mathbf{3}$ foi usada por Fritz Vögtle, da Universidade de Bona, como sensor óptico para iões $\mathrm{Ba}^{2+}[6]$. Esta estrutura contém uma unidade do tipo corante azo que se estende do azoto do grupo amina até ao grupo nitro. É certo que os corantes azo são cromóforos muito conhecidos na indústria.

\footnotetext{
1 School of Chemistry, Queen's University, Belfast BT9 5AG, Northern Ireland

* artigo "Photoionic Supermolecules: Mobilizing the charge and light Brigades" publicado na revista J. Chem. Ed., 53 (1997) 74. Traduçẩo e publicaçăo autorizada pelos autores e editores para a Química. Tradução de A. J. Parola, revisão dedicada de M. J. Melo, consultor cientifico F. Pina.
} 


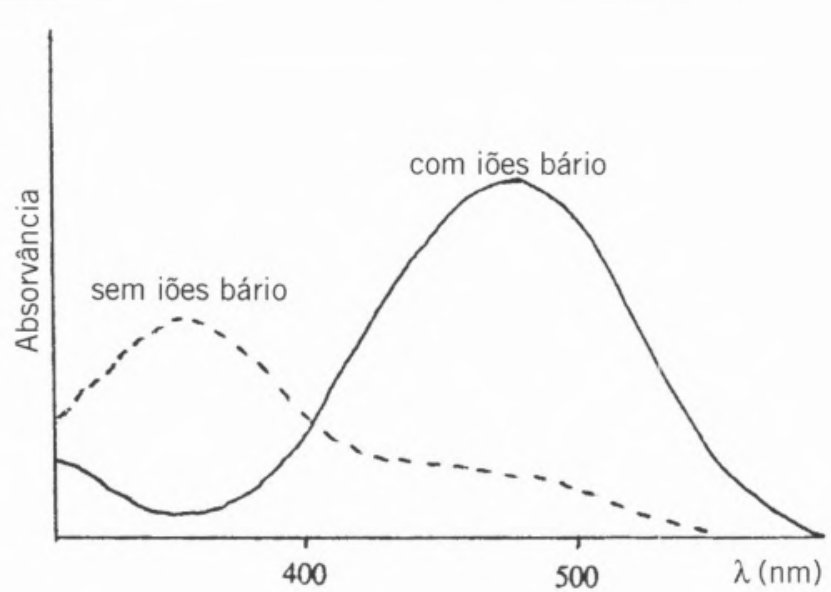

Para o seu receptor de iões, Vögtle escolheu uma unidade de éter de coroa susbstituída no azoto. Os éteres de coroa apareceram em cena em 1967, nos laboratórios de Charles Pedersen, na DuPont, em Wilmington, Delaware [7]. Uma molécula com uma cavidade circular, como é o caso dos éteres de coroa, permanece ainda hoje como um ícone da química supramolecular [8]. No caso do sensor 3, o seu espectro de absorção sofre um desvio de 477 nm para $357 \mathrm{~nm}$ após contacto com iões $\mathrm{Ba}^{2+}$ (Fig. 1). Os sensores ópticos para iões têm uma importância crescente devido à necessidade cada vez maior de monitorizar as concentrações de vários iões presentes nos fluídos biológicos, com testes simples.

\section{Desfrutando a luz mais brilhante}

\section{Harnessing the Brighter Light}

Os sensores fluorescentes para iões podem ser ainda mais sensíveis do que aqueles baseados na absorção de luz, como o sensor 3 , devido à maior facilidade de detecção da fluorescência contra um fundo escuro. Esta sensibilidade significa que a quantidade de sensor necessária para um determinado uso se torna muito pequena. Uma das aplicações mais úteis e interessantes de supramoléculas como sensores de fluorescência é como espias de iões em células vivas. 0 perigo cle envenenar as células é reduzido dado que a quantidade de sensor utilizado está bastante abaixo da dose letal. De um ponto de vista mais geral, as espias são menos susceptiveis de serem detectadas e neutralizadas, ou ainda de serem alimentadas com falsa informação pelo sistema hospedeiro, se figura 1. Espectro de absorção do sensor 3 na ausência e na presença de iões $\mathrm{Ba}^{2+}$. Retirado de Acc. Chem. Res. 1985, 18, 65, com permissão de uso do Copyright da American Chemical Society (1985). existirem em número reduzido. Para além disso, a emissão de fluorescência constitui o modo mais visual de canalizar a informação reunida por espias. Um microscópio de fluorescência pode criar uma imagem da concentração de iões através da luz emitida pelas sondas distribuídas no interior da célula. Claro que a imagem de fluorescência segue os movimentos dos iões em tempo real. Deste modo, esta categoria de supramoléculas fotoiónicas fornece aos biólogos um método que permite observar literalmente, como no cinema, os movimentos iónicos no interior de células vivas, nas mais diversas condições.

Roger Tsien, actualmente na Universidade da Califórnia - San Diego, é um dos pioneiros por detrás deste serviço químico vital para a comunidade das ciências da vida, sendo 4 um dos seus sensores que goza de popularidade considerável na monitorização intracelu-

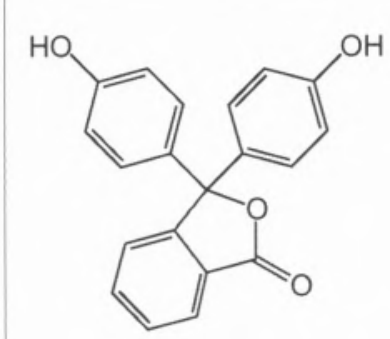

1

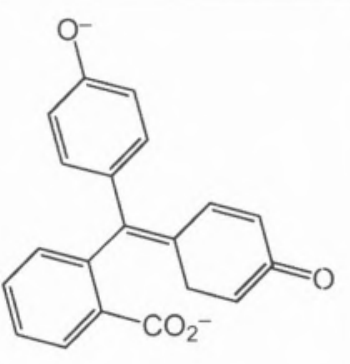

2

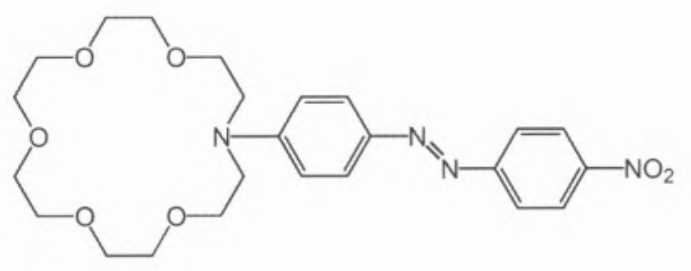

$\mathbf{3}$ 

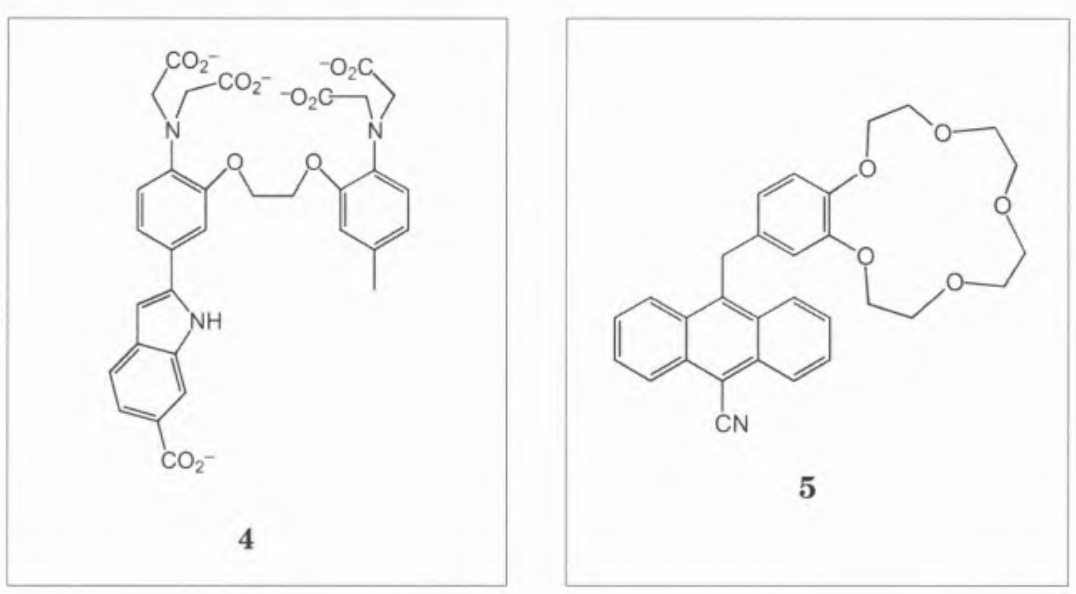

lar de $\mathrm{Ca}^{2+}$ [9]. A parte de cima de 4 contém um receptor para $\mathrm{Ca}^{2+}$, uma espécie de fenda contendo grupos carboxilato, azotos de aminas e oxigénios de grupos éter. 0 fluoróforo inclui o carboxilato ligado ao indol e o grupo aminofenilo também a ele ligado. De tal modo que os componentes para a interacção com fotões e com $\mathrm{Ca}^{2+}$ estão consideravelmente sobrepostos. A ligação de iões ao receptor 4 e derivados origina desvios nos espectros de emissão e de excitação de fluorescência que correspondem, de um modo geral, aos desvios nos espectros de absorção observados em 3. Uma monitorização dual da fluorescência torna-se assim possivel, em que a variação da intensidade de fluorescência a um dos comprimentos de onda é a observação chave, sendo a correspondente variação no segundo comprimento de onda utilizada como referência interna, para compensar problemas que possam surgir na monitorização de situações intracelulares. Esses problemas podem incluir variaçōes na quantidade de sensor incorporado, espessuras ópticas e diversos graus de supressão de fluorescência ao longo da célula.

Um conjunto importante de supramoléculas fotoiónicas, úteis como sensores fluorescentes, utiliza sítios espacialmente afastados para receber fotões e iões, respectivamente [10]. Os seus mecanismos de acção inspiram-se no processo fotossintético, que mantém a vida. A absorção de luz solar nos cloroplastos das plantas origina a transferência de um electrão entre as unidades de clorofila e de quinona, inseridas em sítios diferen- tes na matriz proteica. Construimos uma transferência electrónica fotoinduzida (PET) semelhante a essa, entre um fluoróforo e um receptor de iões, separados por um espaçador convenientemente colocado. É certo que a presença de um canal PET serve como escoadouro da energia depositada no fluoróforo por absorção de luz. Por isso, a supramolécula é, quando muito, fracamente fluorescente. Porém, isto é verdade apenas na ausência de iōes que interactuem com o receptor. Quando os iōes certos atingem uma concentração suficientemente elevada, o receptor fica ligado ao ião e indisponivel para participar num processo PET. A energia da luz absorvida é então devolvida como fluorescência- um sinal nítido de entrada de um ião no receptor. Um exemplo é o sistema $\mathbf{5}$, que sinaliza a presença de iões $\mathrm{Na}^{+}$com uma fluorescência azul. Repare-se no receptor de éter de coroa para o $\mathrm{Na}$ + e no fluoróforo de cianoantraceno, claramente separados por um espaçador de metileno. Estes sensores apresentam uma interrupção "on-off" da fluorescência e não um desvio de comprimentos de onda, como observado em 4, por exemplo.

Um outro tipo de sensor supramolecular utiliza dois fluoróforos de modo a originar uma marca especial de fluorescência, quando um normal estado excitado singleto de um fluoróforo se cola a um outro fluoróforo, não excitado, do mesmo tipo. Estes dímeros ou excímeros excitados sâo normalmente umas sanduíches moleculares. Os seus comprimentos de onda de emissão são maiores do que aqueles dos monóme-

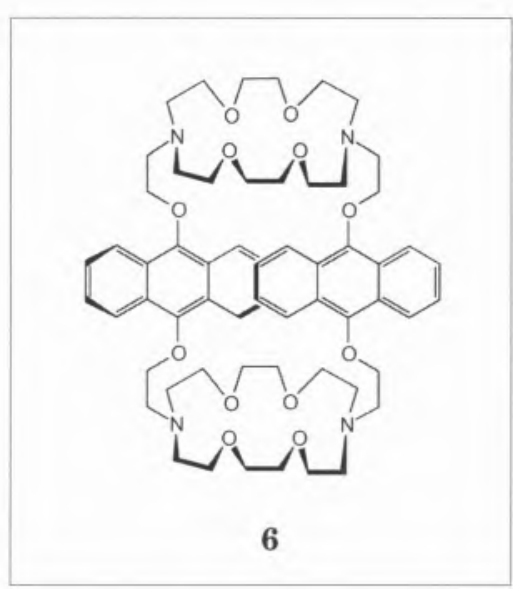

ros devido à maior deslocalização do sistema de electrões $\pi$. Os tempos de vida tendem também a ser mais longos. $\mathrm{O}$ equilíbrio entre excímero e monómero pode ser deslocado por ligação a iões se, na supramolécula forem construídos receptores em locais adequados. Mais uma vez, a presença de iões pode ser detectada por mudanças nos espectros de fluorescência. Consideremos o sistema 6 , resultante de uma colaboração entre Jean-Marie Lehn, em Estrasburgo, e Jean-Pierre Desvergne e Henri BouasLaurent, em Bordéus [11]. 0 sensor 6 prende $\mathrm{H}_{3}{ }^{+} \mathrm{N}\left(\mathrm{CH}_{2}\right)_{6} \mathrm{~N}^{+} \mathrm{H}_{3}$ entre as duas unidades de antraceno como resultado da complexação de cada um dos grupos amónio a um dos éteres de coroa substituídos nos azotos. A estrutura em "hotdog" obtida pela inserção do catião alquildiamónio, em forma de tubo, entre os antracenos planos, impede a formação da sanduíche de excímero. A estrutura relativamente rígida de 6 permite uma sinalização selectiva por fluorescência do catião alquildiamónio C6 relativamente a colegas mais compridos ou mais curtos.

\section{Usando a Emissão Retardada}

\section{Using Delayed Emission}

A área de diagnóstico médico começou recentemente a beneficiar com as supramoléculas fotoiónicas que apresentam emissão de luz retardada. Os compostos orgânicos que contêm carbono, hidrogénio e alguns outros átomos leves, geralmente, emitem luz durante um curto período, de alguns nanosegundos, após terem sido excitados. Por 


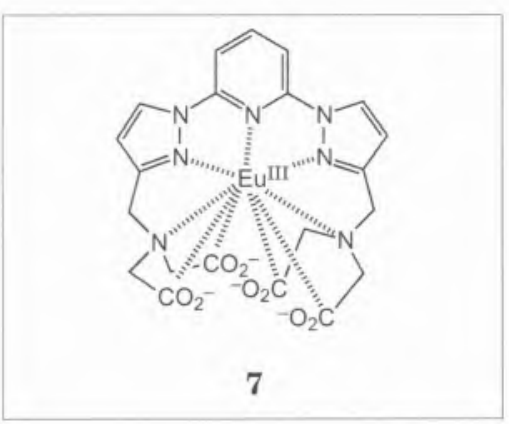

outro lado, quando um composto orgânico se liga a um átomo metálico pesado são introduzidas cargas eléctricas nucleares elevadas e, subsequentemente, perturbações magnéticas fortes. Entre outros efeitos, estas perturbações dão origem ao aparecimento de estados excitados com tempos de vida longos, da ordem dos micro e milisegundos. Os iôes metálicos dos lantanídeos constituem um exemplo excepcional, possuindo uma capacidade impar de absorver e emitir luz de per si. As suas capacidades podem, contudo, ser grandemente amplificadas por complexação com ligandos. Os ligandos funcionam como antenas, canalizando para o ião lantanídeo a energia luminosa captada pelos sistemas $\pi$.

Um outro papel dos ligandos consiste na protecção do ião lantanídeo em relação às moléculas de água, que conseguem escoar a energia do estado excitado do metal por via das vibrações $\mathrm{O}-\mathrm{H}$. $\mathrm{O}$ complexo de $\mathrm{Eu}^{3+}, 7$, é um exemplo recente deste tipo, vindo do laboratório de Juan Rodriguez-Ubis, na Universidade Autónoma de Madrid [12]. Se usarmos um pulso de luz muito curto na excitação, qualquer luz absorvida pelas moléculas da matriz proteica, sempre presente, seria rapidamente emitida como fluorescência. Se usarmos a estratégia da observação tardia, a fluorescência da matriz será ignorada e a emissão de luz retardada do complexo metálico permanecerá então como um farol (sinal luminoso).

A observação na prática de ambientes reais de sistemas vivos pode tornar-se muito mais simples usando este tipo de complexos metálicos, e assim uma revolução tranquila encontra-se em curso em laboratórios hospitalares. A elegante

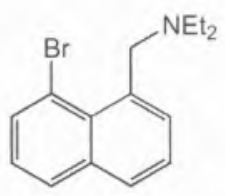

8

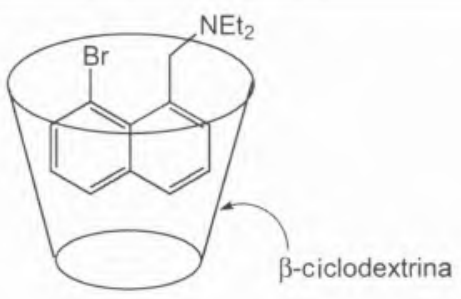

9 técnica analítica dos testes radioimunológicos tem permitido a detecção de drogas e de outras espécies de interesse clínico. Esta técnica é conceptualmente brilhante, ao combinar a elevada sensibilidade de detecção de um marcador radioactivo com a capacidade de aprendizagem do sistema imunitário, que the permite então ligar selectivamente um alvo biológico. Contudo, na prática, o controle do manuseamento de material radioactivo é cada vez mais apertado. A detecção de emissão de luz retardada proveniente de anticorpos marcados com complexos de lantanídeos evita os perigos da radioactividade, mantendo um bom nivel de sensibilidade nos ensaios [13].

A emissão de luz retardada de estados excitados de compostos orgânicos pode também ser incorporada em sistemas fotoiónicos. Tal como no caso da complexação com ic̃es metálicos, a substituição com atómos pesados não-metálicos, como o bromo no composto 8 , pode levar ao aparecimento de estados excitados tripleto que podem emitir luz por periodos na ordem dos milisegundos. Porém, contrariamente aos respectivos estados singleto, o magnetismo inerente aos estados excitados tripleto torna-os vulneráveis a processos de perda de energia por interacção com outras espécies magnéticas. 0 oxigénio molecular é o principal culpado, mesmo em concentrações muito baixas. A autoaniquilação de dois estados excitados tripleto por colisão consitui outro acontecimento provavel em tripletos, sem dúvida facilitado pelos seus inerentemente longos tempos de vida. É então, sem surpresa, que verificamos que a emissão de luz por estados tripleto moleculares, ou fosforescência, em soluções à temperatura ambiente, é um pro- cesso bem menos comum do que a emissão a partir de estados excitados singleto. Contudo, se se tornar possível o processo de fosforescência, a vantagem de uma emissão retardada pode ter um uso feliz, como no caso dos complexos de lantanídeos. 0 nosso sensor de $\mathrm{pH}, \mathbf{9}$, constitui um desses exemplos [14]. Necessitamos de impedir interacções colisionais com os estados excitados tripleto de $\mathbf{8}$, potencialmente fosforescentes, mas permitir a entrada e saída de fotões.

As ciclodextrinas, constituídas por várias unidades de glucose, e outras moléculas do mesmo género têm sido usadas como contentores moleculares transparentes para compostos orgânicos fosforescentes, como o 1-bromonaftaleno. No entanto, se o composto 8 deve funcionar como sensor de $\mathrm{pH}$, é importante que o grupo amina permaneça acessivel, para actuar como receptor de protões do meio. Por outras palavras, a unidade de bromonaftaleno deve ficar enfiada no interior da ciclodextrina enquanto que o grupo amina deve ficar orientado para a fase aquosa externa. Parte da solução deste problema resulta do facto da supramolécula $\mathbf{8}$ apresentar os sítios para interacção, respectivamente com fotões e protões, separados espacialmente, de modo que os requisitos mutuamente exclusivos dos dois sítios podem ser tidos em conta através de uma correcta orientação de $\mathbf{8}$ no interior da ciclodextrina. Curiosamente, o composto 8 é capaz de se auto-orientar regioselectivamente, porque a zona hidrofóbica de bromonaftaleno se enterra na ciclodextrina para evitar o contacto com a água, enquanto o grupo amina, menos hidrofóbico, aponta para o exterior. A acção de detecção de protão por parte do complexo "host-guest" 9 ba- 


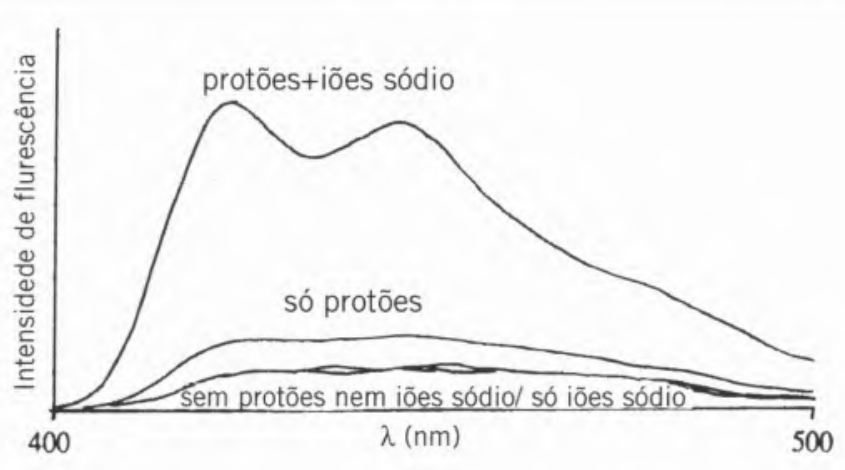

seia-se no aparecimento de fosforescência quando os protões se avizinham do grupo amina. Um processo PET suprime a fosforescência quando o grupo amina se encontra desprotonado, de forma semelhante ao observado com o sensor de fluorescência de $\mathrm{Na}^{+}, \mathbf{5}$. Deste modo, o sistema $\mathbf{9}$ funciona como sensor fosforescente de $\mathrm{pH}$ que pode ser usado numa vizinhança intrinsecamente fluorescente.

\section{Libertando com iões uma luz reprimida}

\section{Ionically Releasing Pent-up Light}

Até ao momento, temo-nos concentrado na exploração de supramoléculas fotoiónicas como sensores ópticos. Uma vez que a detecção é um processo contínuo, torna-se necessária uma fonte de energia para manter o sensor activo. Os sensores moleculares ópticos, baseados quer em absorção quer em emissão, obtêm a sua energia através da luz de excitação. Quando se pretendem determinações muito sensiveis, as próprias fontes de luz usadas na excitação introduzem alguma complicação. Especialmente em soluções não homogéneas, comuns no trabalho dos biólogos, uma parte da radiação de excitação dispersase, chegando ao sistema de detecção de luz. Isto pode interferir com a observação de fluorescência, se os comprimentos de onda de excitação e de emissão se encontrarem próximos.

Há, contudo, muitas aplicações em diagnóstico biológico e médico que necessitam apenas de uma medida isolada e não de uma monitorização contínua. Nessas situações, é possível evitar o uso de qualquer fonte de excitação luminosa e ainda assim observar emissão de luz. Daqui sai um dos mais sensiveis métodos de detecção molecular conhecidos. A energia electrónica aprisionada nalgumas moléculas especiais pode ser termicamente libertada como luz. Alguns organismos especiais conseguem efectuar este processo enzimaticamente. A luz de baixa intensidade resultante de processos quimio/bioluminescentes tem fascinado muitos desde a antiguidade e deu origem a algumas histórias de fantasmas. Se este tipo de emissão de luz puder ser desencadeada por iões, poderão surgir sistemas fotoiónicos com características impares. Por exemplo, a proteína marinha aquorea "acenderá" a sua luminescência quando presenteada com iões $\mathrm{Ca}^{2+}$ [15]. De facto, a aquarina desempenhou um papel importante nas primeiras medições dos niveis de $\mathrm{Ca}^{2+}$ intracelulares em sistemas vivos. Existem moléculas mais pequenas com características semelhantes. 0 dioxetano 10 é praticamente não quimiluminescente até se encontrar desprotonado, a valores de $\mathrm{pH}$ elevados, onde $\mathrm{o}$ anel de dioxetano colapsa libertando luz [16]. Este efeito desestabilizante dos grupos fenolato, ricos em electrões, tem sido explorado no "design" de oxetanos para ensaios de alta sensibilidade para enzimas, como a fosfatase alcalina [17]. Toda uma gama de análises biologicamente importantes poderá então ser testada, unindo a enzima a sondas de ácidos nucleicos ou anticorpos $[13,18]$. figura 2 Espectros de emissão de fluorescência da porta lógica fotoiónica AND 11 para diferentes "inputs" iónicos. Retirado de Nature 1993, 364, 42, com permissão de uso do Copyright da Macmillan Magazines, Limited (1993).

\section{Lógica Molecular com Iões e Luz}

\section{Molecular Logic with lons and Light}

Para além de aplicações em detecção e em diagnóstico, as supramoléculas fotoiónicas começam também a ser usadas no "design" de processadores de informação moleculares. A possível existência de computadores moleculares sintéticos já tem feito incursões no imaginário popular. $\mathrm{O}$ facto de todos termos excelentes exemplos a rechear as nossas cabeças reforça essa atracção. Ainda assim, podemos começar a dar alguns passos na direcção deste "Santo Graal". A revolução electrónica deixou uma marca indelével na vida dos finais do século XX. Entre os principais revolucionários, encontram-se as portas lógicas, cujas tabelas de verdade nos são apresentadas quando adolescentes. Por exemplo, uma porta "AND" de duas entradas ("input") fornecerá um "output" de 1 apenas quando ambos os "bits" de entrada forem 1. Se ambos ou um dos "input" for 0 , o output será 0 . Mimetizar molecularmente o comportamento destes elementos lógicos constituiria um marco importante. $\mathrm{O}$ que se pretenderia não seria uma reprodução fiel desses dispositivos a nível molecular mas antes emular as suas características "input / output". Contrariamente aos seus análogos de estado sólido, de muito maiores dimensões, os dispositivos moleculares electrónicos apresentam sérias dificuldades, até a nivel do seu "design". Uma vez que todos os sinais de entrada e de saída são qualitativamente semelhantes (i. e., electrónicos), pode-se prever que as "conversas cruzadas" entre os diferentes canais terão um impacto forte 

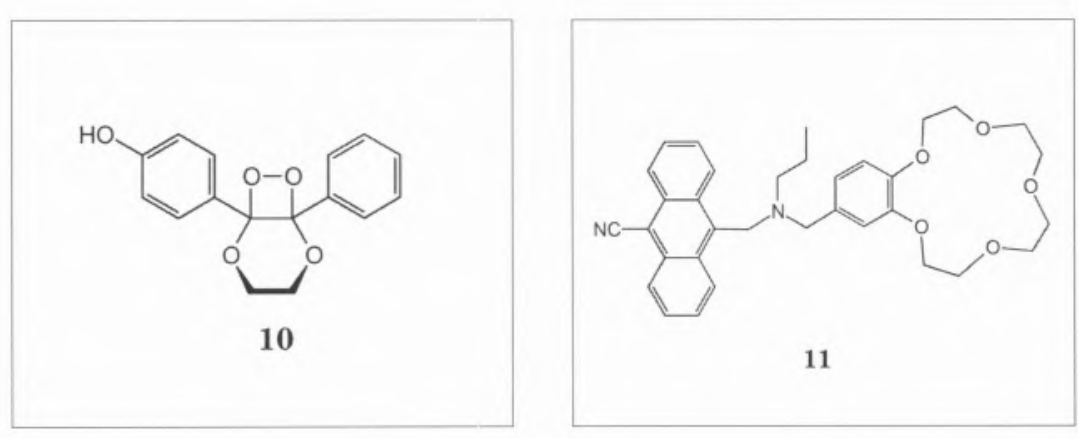

para estas distâncias moleculares. Esta situação pode ser combatida, utilizando um conjunto de sinais e uma fonte de energia qualitativamente diferentes entre si e, por isso, distinguíveis. Para os diferentes "inputs", podemos usar vários iões, dado que o reconhecimento de iões é um percurso já bem conhecido na química. 0 sinal de "output" poderá ser fluorescência por fotões, tendo como fonte de energia a luz absorvida a um menor de comprimento de onda. 0 poder distinguir diferentes iões e luz de diferentes cores faz da aproximação fotoiónica um caso único para o objectivo presente. Para além disso, uma supramolécula pode auto-seleccionar os iões certos para as correspondentes unidades receptoras e os fotões incidentes para o compartimento do fluoróforo.

O mecanismo de interrupção de fluorescência baseado no PET, acima exposto na concepção de sensores, pode agora ser usado no "design" do sistema lógico 11 [19]. O sistema 11 contém um fluoróforo de cianoantraceno que recebe energia e produz o sinal fluorescente de "output". Os "inputs" iónicos $\mathrm{Na}^{+}$e $\mathrm{H}^{+}$ são captados, respectivamente, pelos receptores benzo-éter de coroa e amina, sendo utilizadas concentrações de $\mathrm{H}^{+}$ $10^{-3} \mathrm{M}$ e de $\mathrm{Na}^{+} 10^{-2} \mathrm{M}$ para fornecer níveis elevados dos dois "inputs". Qualquer um dos receptores pode participar num processo PET com o fluoróforo e, desse modo, suprimir a energia depositada pela absorçăo do fotão incidente, i. e., o "output" de fluorescência é desligado. A ligação do catião apropriado $\left(\mathrm{Na}^{+}\right.$ ou $\mathrm{H}^{+}$) ao seu receptor fecha o respectivo processo PET, mas a fluorescência só estará "ligada" quando ambos os receptores estiverem ocupados com o catiãohóspede (fig. 2). A Tabela de Verdade correspondente é mostrada na Tabela 1. Uma resposta deste tipo representa a acção de uma porta lógica fotoiónica "AND".

\section{Bombas de Iões accionadas por Luz}

\section{Light-Driven Ion Pumps}

A importância da rodopsina como supramolécula fotoiónica já foi referida na introdução. A bacteriorodopsina, que se pode encontrar nos habitantes bacterianos de charcos salgados, é um exemplo de um transportador de iões controlado pela luz, que é usado para a produção de energia e não no processamento de sinais [20]. Os químicos têm usado o seu engenho para construir modelos sintéticos destes belos sistemas naturais. Uma das aproximações explora as modificações geométricas da molécula de azobenzeno induzidas pela luz. Os isómeros cis e trans do azobenzeno podem ser interconvertidos reversivelmente com diferentes comprimentos de onda. Para além disso, a forma cis pode ser convertida termicamente na forma trans. Uma implicação importante é o controle da ligação iónica através da geometria do ligando ou receptor: uma das primeiras generalizações da química supramolecular.

Estas duas ideias foram amalgamadas por Seiji Shinkai, actualmente na Universidade de Kyushu, através da inclusão de uma unidade de azobenzeno num éter de coroa [21]. A estrutura híbrida 12 liga-se a $\mathrm{Na}^{+}$na forma cis, mas não na forma trans. A iluminação da forma 12-trans leva à formação da forma 12 -cis e à subsequente captação de $\mathrm{Na}^{+}$, enquanto que a reconversão

Tabela 1. Tabela -de verdade para a porta lógica fotoiónica "AND" 11

\begin{tabular}{llc}
$\begin{array}{l}\text { Primeiro "input" } \\
\text { nível de }\left(\mathrm{H}^{+}\right)\end{array}$ & $\begin{array}{l}\text { Segundo "input" } \\
\text { nível de }\left(\mathrm{Na}^{+}\right)\end{array}$ & $\begin{array}{c}\text { Fluorescência } \\
\text { nível de "output" }\end{array}$ \\
\hline- (baixo) & - (baixo) & baixo \\
- (baixo) & $10^{-2} \mathrm{M}$ (alto) & baixo \\
$10^{-3} \mathrm{M}$ (alto) & - (baixo) & baixo \\
$10^{-3} \mathrm{M}$ (alto) & $10^{-2} \mathrm{M}$ (alto) & alto
\end{tabular}




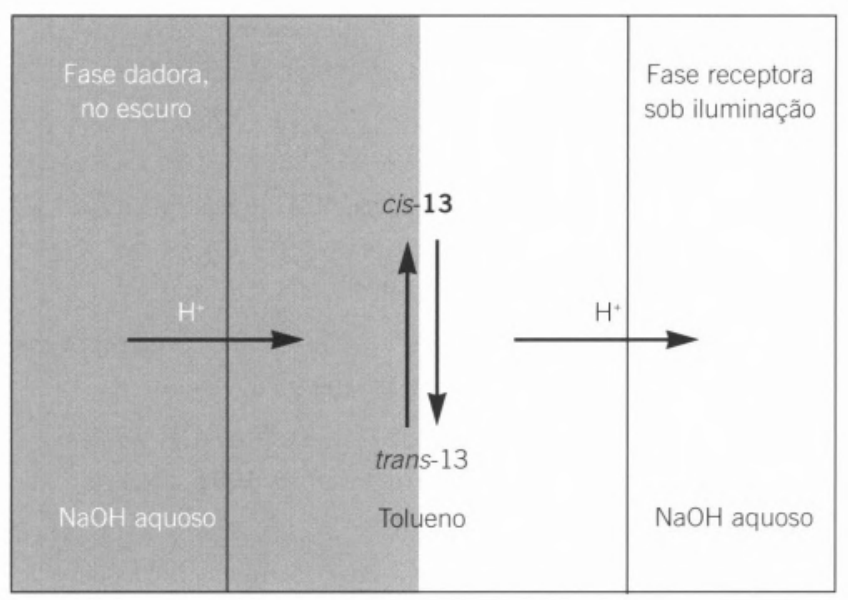

figura 3. Funcionamento da bomba de protões 13. térmica de 12-cis em 12-trans espremerá para fora $\mathrm{Na}^{+}$. A existência de $\mathbf{1 2}$ e derivados permite proceder, pelo menos em princípio, à dessalinização da água do mar usando energia solar. Assim tanques costeiros revestidos com um polímero ligado a $\mathbf{1 2}$ absorveriam sais durante o dia, deixando a água limpa e pronta para ser recolhida antes do anoitecer. Durante a noite, os polímeros libertariam os sais, ficando prontos para recomeçar o ciclo ao amanhecer. 0 tempo nos dirá se este cenário se poderá concretizar.

0 receptor de protões, fenolato, foi ligado a um cromóforo azobenzeno por
Paul Haberfield, da City University de Nova lorque, para demonstrar, num conjunto notavelmente simples de experiências, o transporte de protões sob a influência da luz [22]. A figura 3 dá uma representação esquemática do processo. Neste caso, a estrutura híbrida é um 2-hidroxiazobenzeno, 13, em que a forma trans (predominante no escuro) tem uma acidez baixa devido a uma ligação de hidrogénio intramolecular. Por outro lado, por iluminação produz-se 13-cis, cuja acidez mais elevada permite a passagem de um protão, juntamente com um contra-ião, para a fase aquosa receptora de $\mathrm{NaOH}$. O fenolato 13-cis migra para a fase escura da membrana líquida de tolueno; é acompanhado e estabilizado por um ião tetrabutilamónio, um componente comum em sistemas de transferência de fase. A isomerização térmica do fenolato 13 -cis para o fenolato 13-trans produz a base mais forte, que extrai um protão, juntamente com um contra-ião, da fase aquosa dadora no escuro. $\mathrm{O}$ resultado global é o transporte de $\mathrm{H}^{+}$da fase aquosa dadora, iluminada, para a fase receptora, no escuro.

A unidade de azobenzeno adapta-se muito bem, ainda que de modo não exclusivo, ao "design" de "iões engaiola-
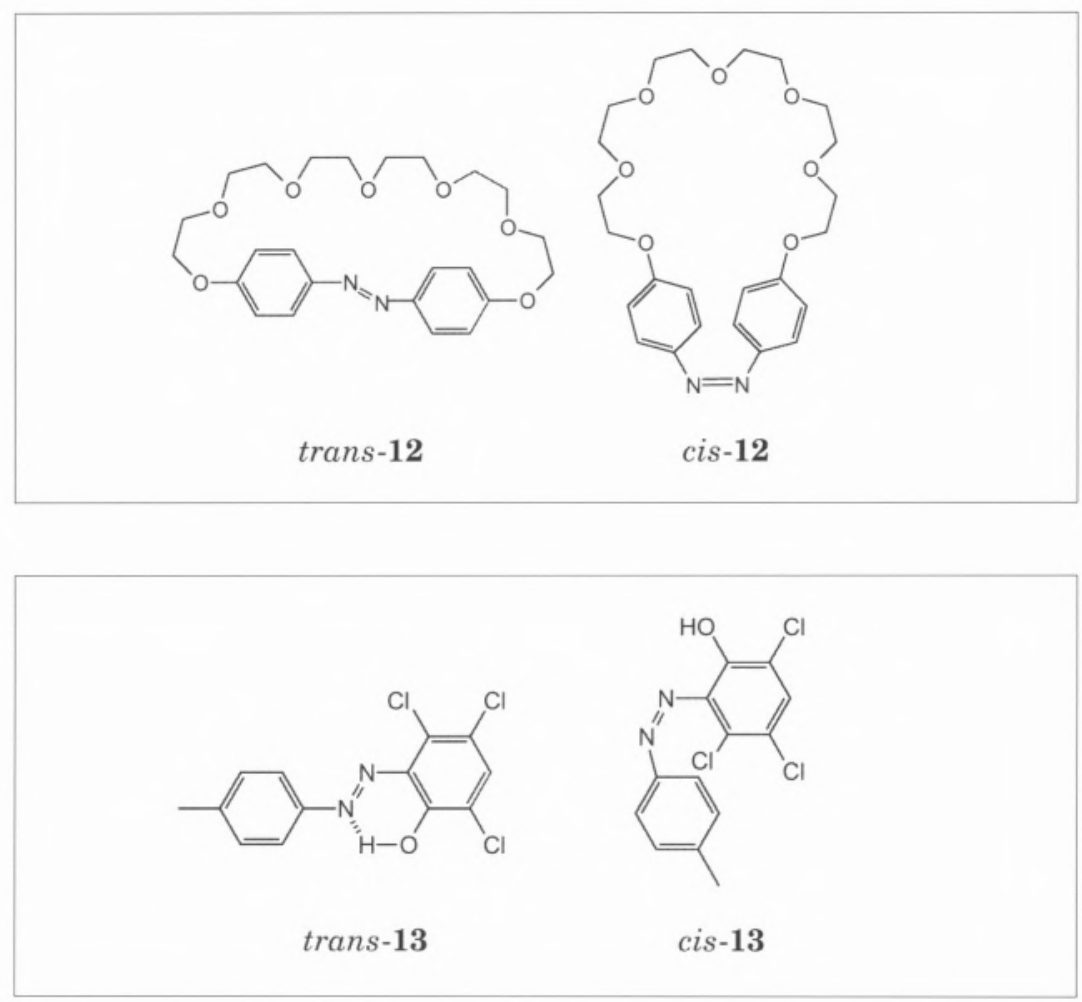
dos", onde a luz funciona como uma chave que destranca a porta da gaiola, permitindo a libertação do ião [23]. Não é necessário que esta foto-libertação de iões seja reversível para muitas aplicações em fisiologia, e alguns sistemas desenvolvidos tiram vantagem de reacções fotoquímicas uni-direccionais para destruir o receptor iónico. Alguns sistemas iluminados podem mesmo ejectar iões durante o tempo de vida do estado excitado. O leitor é encaminhado para um artigo de revisão recente sobre estas moléculas iluminadas [24].

Em conclusão, as supramoléculas permitem transacções (trocas) entre luz e iōes criando sensores ópticos, etiquetas, interruptores e bombas. De uma forma mais geral, as supramoléculas fotoiónicas fornecem meios que podem auxiliar cientistas, numa vasta gama de disciplinas, a dedicar-se a problemas de intenso interesse humano.

\section{Agradecimentos}

$\mathrm{O}$ que aqui foi apresentado é apenas um aperitivo para a enorme quantidade de material muito interessante servido por diversos laboratórios. Por isso, apenas são dadas referências indicativas. Agradecemos o apoio da Queen's University, da University of Colombo, EPSRC/SERC, DENI, Nuffield Founda-

\section{Perfil do Prof. Prasanna de Silva}

O Prof. A. Prasanna de Silva nasceu no Sri Lanka, onde efectuou os seus estudos universitários (BSc pela Universidade de Colombo em 1976). Concluiu o seu doutoramento na Queen's University em Belfast, em 1980. Actualmente é Professor no Departamento de Química da mesma Universidade (http://www.ch. qub.ac.uk/staff/desilva/apds.html), tendo também leccionado na Universidade de Colombo, Srilanka, num período em que a sua avó, que tion, IAESTE, e NATO (grant 921408 em conjunto com J.-Ph. Soumillion da Université Catholique de Lovaina). Agradecemos especialmente a ajuda de Nimal Gunaratne e lan Gibson.

\section{Referências}

1. Principles of Neural Science, 3rd ed.; Kandel, E. R.; Schwartz, J. H.; Jessell, T. M., Eds.; Elsevier: New York, 1991.

2. Lehn, J.-M. Supramolecular Chemistry; VCH: Weinheim, 1995.

3. Balzani, V.; Scarıdola, F. Supramolecular Photochemistry; Ellis-Horwood: Chichester, 1991.

4. Bissell, R. A.; de Silva, A. P; Gunaratne, H. Q. N.; Lynch, P. L. M.; Maguire, G. E. M.; Sandanayake, K. R. A. S. Chem. Soc. Rev. 1992, 21, 187.

5. Indicators; Bishop, E., Ed.; Pergamon: Oxford, 1972.

6. Löhr, H.-G.; Vögle, F. Acc. Chem. Res. $1985,18,65$.

7. Pedersen, C. J. J. Am. Chem. Soc. 1967, 89, 7017.

8. Chenevert, R.; Rodrique, A. J. Chem. Educ. 1984, 61, 465

9. Tsien, R. Y. Am. J. Physiol. 1992, 263, C723.

10. Bissell, R. A.; de Silva, A. P; Gunaratne, H. Q. N.; Lynch, P. L. M.; Maguire, G. E. M.; McCoy, C. P.; Sandanayake, K. R. A. S. Top. Curr. Chem. 1993, 168, 223.

o criou após a morte da mãe, precisava de cuidados.

A. Prasanna da Silva é um químico internacionalmente conceituado, as ideias que tem desenvolvido nos últimos anos são originais e tiveram profundo impacto na comunidade cientifica (ver p.e., http://www.nature.com/nsu/000511/000511-2.html e entrevista no Alchemist http:// www.cqfg.fct.unl.pt/fotoquimica).

Para além disso o Prof. Prasanna da Silva é um comunicador ímpar, tendo participado em programas cientificos da BBC.
11. Fages, F.; Desvergne, J.-P.; Kampke, K.; Bouas-Laurent, H.; Lehn, J.-M; Meyer. M.; Albrecht-Gary, A.-M. J. Am. Chem. Soc. 1993, 115, 3658.

12. Remuinan, M. J.; Roman, H.; Alonso, M. T.; Rodriguez-Ubiz, J. J. Chem. Soc. Perkin Trans. 2 1993, 1099.

13. Mayer, A.; Neuenhofer, S. Angew. Chem. Int. Ed. Engl. 1994, 33, 1044.

14. Bissell, R. A.; de Silva, A. P. J. Chem. Soc. Chem. Commun. 1991, 1148.

15. Cobbold, P. A.; Lee, J. A. C. In Cellular Calcium: A Practical Approach; McCormack, J. G.; Cobbold, P. A., Eds.; IRL: Oxford, 1991; p 55.

16. Schaap, A. P.; Gagnon, S. D. J. Am. Chem. Soc. 1982, 104, 3504.

17. Schaap, A. P.; Sandison, M. D.; Handley, R. S. Tetrahedron Lett. 1987, 28, 1159.

18. Clyne, J. M.; Running, J. A.; Stempien, M.; Stephens, R. S.; Akhavan-Tafti, H.; Schaap, A. P.; Urdea, M. S. J. Biolumin. Chemilumin. 1989, 4, 357.

19. de Silva, A. P.; Gunaratne, H. Q. N.; McCoy, C. P. Nature 1993, 364, 42.

20. El-Sayed, M. A. Acc. Chem. Res. 1992. 25,279 .

21. Shinkai, S.; Manabe, O. Top. Curr. Chem. 1984, 121, 67.

22. Haberfield, P. J. Am. Chem. Soc. 1987, 109, 6177, 6178.

23. Biological Applications of Photochemical Switches; Morrison, H., Ed.; Wiley: New York, 1993.

24. Valeur, B.; Bardez, E. Chem. Br. 1995, 31, 216 .

A.P. como é conhecido entre os numerosos amigos que possui na comunidade científica, tem uma boa disposição a toda a prova. Uma nota pessoal: quando Ihe recordámos que o seu nome deveria de ser de origem portuguesa, logo confirmou. Segundo ele quando da ocupação da sua ilha pelos Portugueses, muitos dos nativos foram batizados com nomes cristãos e se não era a bem era a mal, e com a mão fez o gesto de uma faca apontada ao pescoço. 0 que é um facto é a existência de uma grande empatia entre A.P. e a numerosa comunidade fotoquímica portuguesa. 